Maciej Grochowski •

Instytut Języka Polskiego Polskiej Akademii Nauk, Kraków

magro@umk.pl

\title{
EWOLUCJA KRYTERIÓW PODZIAŁU GRAMATYCZNEGO LEKSEMÓW (RELATORY A SPÓJNIKI) ${ }^{1}$
}

Słowa klucze: język polski, części mowy, historia gramatyki polskiej, składnia, semantyka, jednostki funkcyjne

Keywords: the Polish language, parts of speech, the history of Polish grammar, syntax, semantics, function units

\section{Części mowy a jednostki funkcyjne}

Niezależnie od koncepcji gramatyki, jaką jej autor przyjmuje, konieczne jest operowanie klasami jednostek słownikowych, z których za pomocą określonych reguł tworzy się konstrukcje składniowe. Jednostki są grupowane na podstawie ich wspólnych cech dotyczących formy, funkcji i znaczenia. Zbiór cech wspólnych dla jednostek danej klasy musi ją w jakiś sposób wyróżniać, aby dało się ją przeciwstawić innej klasie jednostek. Integralnym komponentem każdej gramatyki języka naturalnego są więc tzw. części mowy. Przyjmuję, że części mowy to klasy funkcjonalne jednostek leksykalnych (sensu largo) danego języka naturalnego, wyróżnione na podstawie kryteriów gramatycznych lub semantyczno-gramatycznych. Zakładam, że podziałowi podlegają zarówno jednostki jedno-, jak i wielosegmentowe (Bogusławski 1976). Preferuję takie składniowe kryteria podziału, zgodnie z którymi

1 Publikacja przygotowana w ramach projektu NPRH nr $11 \mathrm{H} 17$ 006685, realizowanego w latach 2018-2023. 
jednostki traktowane są jako wielkości znaczące. Nie ma żadnej a priori przyjętej normy co do liczby części mowy, która byłaby konieczna i wystarczająca do zbudowania gramatyki języka polskiego. Są części mowy otwarte, odnoszące się do świata, np. rzeczowniki, i części mowy zamknięte, np. partykuły, odnoszące się do wyrażeń językowych. Sposób traktowania takich klas w gramatyce musi być różny. Dzieje językoznawstwa polonistycznego potwierdzają pogląd, że liczba klas gramatycznych jednostek zależy od kryteriów podziału, stopnia ich szczegółowości i ścisłości, celu badań i woli badacza. Historia badań nad częściami mowy, upowszechniona przede wszystkim dzięki monografiom Mirosława Skarżyńskiego (1994, 2001), pokazuje dominację kryteriów semantycznych w XIX i w pierwszej połowie XX w. i sukcesywne zmiany w tym zakresie; por. też: Jodłowski 1971; Heinz 1978; Urbańczyk 1993; Ulitzka 2008. W drugiej połowie XX w. preferowane są kryteria syntaktyczne.

Począwszy od lat 80. XX w. językoznawcy zajmujący się gramatyką koncentrują uwagę na analizie i klasyfikacji leksemów funkcyjnych (Grochowski 1984, 1986, 1997). Jedną $\mathrm{z}$ istotnych przyczyn kształtowania się takiego kierunku w rozwoju gramatyki jest intensywny rozwój składni opartej na podstawach semantycznych (Karolak 1984) oraz nauki o tekście. Wyodrębniane są nowe klasy jednostek funkcyjnych, badane i uściślane są relacje między znanymi klasami (Wajszczuk 2005; Doboszyńska-Markiewicz 2013; Kleszczowa, Szczepanek 2014). Jedną z takich klas tworzą wyrazy nazywane w dawnych gramatykach zaimkami względnymi, a w pracach gramatycznych i leksykograficznych ostatniego czterdziestolecia (oraz w niektórych słownikach, np. w SWJP i w WSJP PAN) relatorami; por. np. Bobrowski 1995; Wróbel 1996; Laskowski 1998; Ulitzka 2010. Termin ten został zaproponowany w artykule Grochowski 1984 i stosunkowo szybko upowszechnił się w polskiej literaturze syntaktycznej.

Od początku XX w. charakteryzuje się zaimki względne w gramatykach języka polskiego, i to z coraz większą dokładnością, ale opisy tej grupy wyrazów są izolowane, nie porównuje się ich z właściwościami innych grup. Dopiero w latach 8o. XX w. zaimki względne (relatory) zaczyna się przeciwstawiać spójnikom i innym wyrazom o funkcji łączącej, poszukuje się kryteriów ich kwalifikacji składniowej.

Celem tego artykułu jest przedstawienie ewolucji kryteriów wyróżniania relatorów w gramatyce języka polskiego. Ewolucję tę wyznaczają dwa przełomowe momenty w historii językoznawstwa teoretycznego: pierwszy stanowi konsekwencję zastosowania teorii konotacji w badaniach składniowych (por. Kuryłowicz 1936/1979; Milewski 1952/1971), drugi polega na wykorzystaniu opozycji przedmiotowego poziomu języka i poziomu metatekstu w badaniach jednostek funkcyjnych. Klasyczna koncepcja metatekstu Anny Wierzbickiej (1971) znalazła swój wyraz w badaniach Jadwigi Wajszczuk $(1997,2005,2010)$ dotyczących teorii spójników, a później innych części mowy. Najpierw omówię więc krótko sposoby charakterystyki relatorów w pierwszej połowie XX w. (pkt 2), w następnej części artykułu przedstawię miejsce relatorów w klasyfikacjach syntaktycznych leksemów w drugiej połowie 
XX w. (pkt 3). Końcowa część artykułu będzie dotyczyła kryteriów opozycji relatorów i spójników, wynikających z badań Wajszczuk poświęconych operatorom metatekstowym (pkt 4).

\section{Od Krasnowolskiego do Gaertnera}

Części mowy w koncepcji składni Antoniego Krasnowolskiego (1909) nie są scharakteryzowane explicite, nie są nawet wyliczone, możliwość rozumienia odpowiadających im terminów wynika ze sposobu operowania nimi przez uczonego. Krasnowolski wyróżnia zaimki i przysłówki, i odpowiednio zaimki względne (np. kto, co, który, jaki, czyj, ile) i przysłówki względne (np. gdzie, dokąd, skąd, którędy, odkąd, kiedy, dlaczego, jak), tożsame brzmieniowo z pytajnymi, ale w przeciwieństwie do tych ostatnich nieakcentowane. Jednostki obu klas łączą zdanie nadrzędne albo jego składnik ze zdaniem podrzędnym, por. np. Żona śmiać się zaczęła, co go jeszcze większym gniewem napetniło., Panna Agata kłusem pobiegła do sani, gdzie ja Franciszek przyjąt uprzejmie. (ibid.: 296-297). Zaimki względne odpowiadają wskazującym (ten, taki, tyle) w zdaniu głównym, a przysłówki względne przysłówkom wskazującym (tu, tam, stąd, tędy, wtenczas) w zdaniu głównym. Z przytoczonych przykładów, a także z tezy autora (ibid.: 228, 284), że zaimek względny „powinien zgadzać się z określanym lub zastępowanym rzeczownikiem w rodzaju i liczbie”, można wnioskować, że - w przeciwieństwie do przysłówka względnego - jest on wyrazem odmiennym. Krasnowolski (ibid.: 229) wyróżnia ponadto zaimki i przysłówki względne uogólniające $\mathrm{z}$ elementem -kolwiek typu ktokolwiek, gdziekolwiek. W koncepcji składniowej autora (ibid.: 221) nie ma klarownych granic między częściami mowy, świadczy o tym m.in. wyodrębnienie przysłówków spójnikowych, reprezentowanych przez takie ciągi, jak po pierwsze, po drugie, tudzież, także, nadto, to - to, baqdź - baqdź, już to - już to, tak - jak.

Jeden z pierwszych $\mathrm{w}$ XX w. podział wyrazów na dziesięć części mowy, przez wyliczenie ich klas, oparty na bardzo ogólnych kryteriach semantycznych, wprowadził do gramatyki polskiej w 1921 r. Stanisław Szober (1957: 92-105). Operowano nim w literaturze językoznawczej do końca lat 6o. XX w. Przyjęty przez Szobera podział wyrazów na oznaczające (rzeczowniki, przymiotniki, czasowniki, przysłówki, spójniki, przyimki, wykrzykniki), wskazujące (zaimki i partykuły) i oznaczająco-wskazujące (liczebniki i przysłówki odliczebnikowe) krzyżuje się z podziałem na wyrazy samodzielne (wszystkie oprócz trzech wymienionych niżej) i niesamodzielne (spójniki, przyimki, partykuły). Zaimki względne, jedna z siedmiu grup znaczeniowych zaimków, wskazują na przedmioty i reprezentują podgrupę zaimków rzeczownych (np. kto, co, ktokolwiek, cokolwiek, kto bądź, co bądź, kto tylko, co tylko) lub na właściwości przedmiotów i należą wówczas do podgrupy zaimków przymiotnych (np. który, jaki, którykolwiek, jakikolwiek, który bądź, jaki bądź, który tylko, jaki 
tylko). Szober (ibid.: 103) wyróżnia ponadto w klasie przysłówków, wyrazów oznaczających właściwości cech, przysłówki zaimkowe, które dzieli z kolei na cztery podgrupy. Jedną z nich są przysłówki zaimkowe względne, „wskazujące na miejsce, czas, sposób lub jakość cech, czynności i stanów" (ibid.), np. gdzie, skąd, odkąd, dokąd, kiedy, poką, dopóki, póki, jak. Można przypuszczać, że eliminacja wymienionych wyrazów z klasy zaimków była spowodowana tym, że zaimki według Szobera (ibid.: 97) należą do kategorii imion, a więc odmieniają się przez przypadki.

Spójniki opisywał Szober (ibid: 104-105) jako znaki stosunków między wyrazami lub zdaniami, łączące części zdania lub zdania, i dzielił na współrzędne (np. i, oraz, a, ale, lecz, albo, lub, czyli, więc, zatem, toteż) i podrzędne (np. że, iż, aby, żeby, jeśli, jeśliby, gdyby, chociaż, chociażby, bo, ponieważ, gdyż). W charakterystykach zaimków i spójników nie ma ani jednego sądu świadczącego o istnieniu związku między wyrazami należącymi do tych klas, przeciwstawiają się one sobie pod każdym względem: pierwsze wskazują, drugie oznaczają, pierwsze są samodzielne, drugie niesamodzielne, pierwsze odmienne, drugie nieodmienne.

Zasadniczych zmian w podziale semantycznym wyrazów na części mowy nie przynoszą prace Zenona Klemensiewicza (1937, 1938, 1960, 1963), dostrzegał on jednak związek między spójnikami a zaimkami, opisując jednostki obu tych klas jako reprezentantów „wyrazowych wskaźników zespolenia”. Grupę tę tworzą spójniki (,znaki stosunku między dwoma składnikami w wypowiedzeniu pojedynczym lub między dwoma wypowiedzeniami w złożeniu dwuwypowiedzeniowym", Klemensiewicz 1937: 205) i pomocnicze wyrazowe wskaźniki zespolenia, na które składają się zaimki zespolenia i zapowiedniki zespolenia (ibid.). Pierwsze to zaimki wypowiedzenia podrzędnego „bezpośrednio nawiązujące do jednego ze składników wypowiedzenia nadrzędnego", np. jak, dokąd, dopóki, ilekroć, jaki; por. Rób, jak chcesz., Idę, dokąd mi każą. Drugie to zaimki, które uprzedzają następne wypowiedzenie i zarazem zapowiadają je, niekiedy nawiązują do niego; por. np. po to, tam, wtedy, o to w wypowiedzeniach: Wybrałem się do Warszawy po to, żeby wygtosić odczyt., Byłem tam, gdzie ty spędziłeś całe dzieciństwo., Wtedy przybyłem do Warszawy, kiedy ty ja opuściłeś., Pytałem o to, jak wypadł egzamin. (ibid.: 207-209).

Zaimki zespolenia są przypuszczalnie zaimkami względnymi, choć Klemensiewicz, o ile mi wiadomo, nigdzie explicite związku między tymi terminami nie określa. W przeciwieństwie do Krasnowolskiego i Szobera nie ogranicza zbioru zaimków do wyrazów odmiennych, co potwierdza wyróżnienie zaimków względnych przysłownych (Klemensiewicz 1960: 59). W swojej koncepcji składni z okresu międzywojennego Klemensiewicz operował pojęciem składnika wypowiedzenia jako „znaku językowego jednego przedstawienia ustosunkowanego do innych przedstawień z postawy mówiącego" (1937: 44). Zgodnie z tym rozumieniem składnika spójnik jako znak stosunku między składnikami lub wypowiedzeniami sam składnikiem wypowiedzenia nie jest (szerzej Grochowski 2011). Na analogiczne pytanie dotyczące zaimka względnego trudno znaleźć eksplicytną odpowiedź we wczesnych pra- 
cach Klemensiewicza. Uczony, rozwijając charakterystykę zaimków zespolenia dopiero w Zarysie składni polskiej (Klemensiewicz 1963: 73), stwierdza, że stanowią one składniki wypowiedzenia podrzędnego. Uzasadniona jest więc hipoteza, że istotna dla współczesnej klasyfikacji leksemów opozycja spójników i relatorów może mieć swoje źródła m.in. w koncepcji składni Klemensiewicza.

System części mowy, czyli kategorii wyrazów, w gramatyce Henryka Gaertnera (1938: 144-206) różni się od gramatyki Szobera zdecydowanie bardziej rozbudowanym (ale oryginalnym) aparatem terminologicznym i szczegółowością podziałów wewnętrznych oraz opisów niż samą koncepcją merytoryczną. Zaimki są jedną z sześciu klas „wypowiedników zamierzonych” (czyli znaczników), obok rzeczowników, przymiotników, liczebników, czasowników i przysłówków, mają wiele właściwości wspólnych z imionami i często je zastępują. Zaimki względne (ibid.: 173-175) stanowią jedną z dziesięciu grup znaczeniowych klasy nadrzędnej i dzielą się na rzeczowne (np. kto, co), przymiotne (np. jaki, czyj) i liczebne (np. ile, który). Zaimkami nie są wyrazy nieodmienne, takie jak gdzie, kiedy, jak; Gaertner kwalifikuje je jako przysłówki zaimkowe względne (ibid.: 201). Spójniki obok przyimków należą do kategorii „spójek” (ibid.: 205-206), obejmują one spójniki równorzędności, np. $i$, albo, ani, czyli, przeto, lecz, i nierównorzędności, np. bo, chociaż, jeśli, skoro, że (dziś współrzędne i podrzędne); mogą tworzyć powiedzenie tylko w połączeniu ze znacznikiem.

\section{Od Milewskiego do Laskowskiego i Wróbla}

Badania z zakresu teorii części mowy, prowadzone metodami ukształtowanymi przez strukturalizm europejski, zainicjowali w językoznawstwie polskim Jerzy Kuryłowicz i Tadeusz Milewski. Kuryłowicz (1936/1979), badając zależność między wartością leksykalną wyrazu a jego funkcją składniową, zbudował system podstawowych części mowy, złożony z czterech klas (rzeczowników, przymiotników, czasowników i przysłówków), oraz system klas wyrazów niemających funkcji symbolicznej (tworzyły go wykrzykniki i zaimki) bądź samodzielnej funkcji składniowej (należały do niego przyimki, spójniki, liczebniki główne i rodzajniki). Milewski (1952/1971) pod wpływem teorii Kuryłowicza, odwołując się do takich "technik lingwistycznych”, jak konotowanie, nazywanie, wskazywanie i szeregowanie, zaproponował podstawowy system części mowy - wyrazów nazywających (zawierający rzeczowniki, przymiotniki, przysłówki i czasowniki) i systemy pochodne - wyrazów wskazujących (zaimków) oraz szeregujących (liczebników). Podstawą przynależności wyrazów do tej samej części mowy są, według Milewskiego (ibid.: 24-25), wspólne cechy ich wartości leksykalnej oraz tożsamość ich miejsca w schematach syntaktycznych. Członami syntaktycznymi nie są przyimki, spójniki, partykuły i wykrzykniki, stanowią one luźne morfemy o funkcji wykładników kategorii gramatycznych. 
Charakteryzując kategorię zdań złożonych, Milewski (ibid.: 33-34, 1965: 112) podaje (nie jest wykluczone, że spośród syntaktyków polskich jako pierwszy) cechy dystynktywne zaimków względnych i spójników. Zaimek względny łączy w sobie funkcję zaimka pytajnego i anaforycznego, wskazuje równocześnie wstecz, na człon zdania głównego, i naprzód, na zdanie poboczne, które ma po nim nastąpić. Jest zawsze członem konotowanego przez siebie zdania pobocznego i pełni funkcję łącznika dwóch zdań, np. Weszli do miasta, które wyrosło przed nimi. Spójnik nie wskazuje na poprzedzające zdanie, lecz konotuje dwa miejsca po obu swoich stronach i łączy zdania składowe zdania złożonego.

Nadrzędnym kryterium klasyfikacji gramatycznej leksemów w ujęciu Zygmunta Saloniego (1974) była ich odmienność. Leksemy odmienne autor podzielił według kryteriów fleksyjnych na pięć klas (rzeczowniki, przymiotniki, liczebniki, czasowniki właściwe i niewłaściwe - te ostatnie nieodmienne przez osobę), a leksemy nieodmienne według kryteriów syntaktycznych na cztery klasy (partykuło-przysłówki, przyimki, spójniki i wykrzykniki). Podział ten rozszerzył nieco Marek Wiśniewski (1995), w prowadzając nowe kryteria i oddzielając partykuły od przysłówków, a także rozróżniając wykrzykniki i dopowiedzenia. Leksemy zaliczane tradycyjnie, na podstawie kryteriów semantycznych, do zaimków, a w konsekwencji i zaimki względne, znalazły się odpowiednio w klasach rzeczowników, przymiotników, liczebników i partykuło-przysłówków (u Wiśniewskiego w klasie przysłówków). Zalety i wady takiego rozwiązania podkreślano w literaturze wielokrotnie; por. np.: Laskowski 1984, 1998; Wróbel 1996; Wajszczuk 1997.

Spójniki zostały uznane przez Saloniego za leksemy nieodmienne, nieużywane samodzielnie (w opozycji do wykrzykników), łączące (w opozycji do partykuło-przysłówków) i niemające rządu przypadkowego (w opozycji do przyimków).

Stanisław Jodłowski (1976: 13-23), wyróżniając w swoim podręczniku składni jedenaście części mowy, łączył kilka odległych od siebie kryteriów. Dotyczyły one, oprócz składni i morfologii, postawy mówiącego wobec otaczających go zjawisk, sposobów ujmowania składników rzeczywistości w treści wyrazów (kryterium to nazywał autor epistemologicznym) oraz sposobu kierowania uwagi odbiorcy na przedmiot (odwołującego się do pamięci - mnemiczny lub do sytuacji - niemnemiczny). Ogólną charakterystykę zaimków, klasy składniowo i morfologicznie heterogenicznej, Jodłowski (ibid.: 20) ograniczył do jednej etykietki, nazwał je „wyrazami denotującymi niemnemicznie". Spójniki zostały scharakteryzowane jako wyrazy denotujące, mnemiczne, nienazywające i „zaznaczające stosunki międzywyrazowe równorzędne oraz stosunki międzyzdaniowe niedenotowane zaimkami względnymi i pytajnozależnymi” (ibid.). Uznanie danego wyrazu za spójnik wymaga więc wcześniejszego wykluczenia go ze zbioru zaimków względnych, tymczasem klasa ta nie została przez autora scharakteryzowana.

Klasyfikacje funkcjonalne leksemów Romana Laskowskiego (1984, 1998), zarówno podstawowa, jak i zmodyfikowana, oparte są na opozycji prymarnych i sekundar- 
nych funkcji syntaktycznych leksemów, odwołują się do pojęcia zależności syntaktycznej, a tym samym, implicite, również do pojęcia konotacji. Jedna z nadrzędnych dychotomii (pomijam tu asyntagmatyki, nieistotne dla dalszych rozważań) w pierwszej klasyfikacji polega na przeciwstawieniu autosyntagmatyków i synsyntagmatyków, a w drugiej - leksemów samodzielnych i niesamodzielnych składniowo, krótko mówiąc, jednostek zdolnych do pełnienia funkcji składnika wypowiedzenia i niemających tej cechy. Synsyntagmatyki (nieautosyntagmatyki) są wskaźnikami relacji syntaktycznych między składnikami wypowiedzenia (z wyjątkiem leksemów nazywanych „partykułami”, niemających funkcji łączącej) i obejmują konektory względne, spójniki (tylko w pierwszej klasyfikacji dzielone na podrzędne i współrzędne) i przyimki. Pierwsze, nazywane $\mathrm{w}$ drugiej klasyfikacji relatorami, „w przeciwieństwie do spójników [...] zajmują pozycję syntagmatyczną składnika zależnego syntaktycznie (podrzędnego) wyrażenia zdaniowego" (Laskowski 1984: 32). Spójniki, analogicznie do relatorów, łączą wyrażenia zdaniowe, ale nie są członami tych wyrażeń. Niektóre spójniki mogą łączyć również komponenty wyrażenia niezdaniowego (Laskowski 1998: 58). Zaliczenie relatorów do synsyntagmatyków, a więc klasy leksemów, które nie są składnikami wypowiedzenia, jest sprzeczne ze stwierdzeniem, że mogą one zajmować pozycję składnika w wypowiedzeniu zależnym.

W artykule rozszerzającym syntaktyczne kryteria podziału leksemów Saloniego (1974) i pierwszą klasyfikację funkcjonalną Laskowskiego (1984) zaproponowałem (Grochowski 1984) klasyfikację leksemów nieodmiennych. Relatory zostały w niej scharakteryzowane jako leksemy nieużywane samodzielnie, mające funkcję łączącą, niemające rządu przypadkowego i zajmujące pozycję syntaktyczną składnika jednego z łączonych wyrażeń (w opozycji do spójników, które nie mają tej ostatniej własności). Wymienione właściwości relatorów i spójników zaaprobowała Viara Maldjieva (1995: 49) i zastosowała w analogicznej do mojej klasyfikacji leksemów nieodmiennych w językach bułgarskim, rosyjskim i polskim.

Niedługo przed opublikowaniem zmodyfikowanej klasyfikacji Laskowskiego swoją propozycję klasyfikacji syntaktycznej leksemów przedstawił Henryk Wróbel (1996); upowszechnił ją wkrótce - w nieco zmodyfikowanej wersji (zmiany te nie miały wpływu na opozycję relatorów i spójników) - w autorskim podręczniku gramatyki (Wróbel 2001: 73-81). W propozycji tej autor korzysta w niemałym stopniu, co zresztą explicite stwierdza (Wróbel 1996: 56-60), z klasyfikacji Laskowskiego (1984) i mojej (Grochowski 1984). Charakterystyka relatorów w ujęciu Wróbla nie zawiera wspomnianej wyżej sprzeczności.

Nadrzędnym kryterium klasyfikacji Wróbla (1996) jest podział leksemów na używane samodzielnie jako wypowiedzenia (dopowiedzenia i wykrzykniki) i niemające tej cechy, czyli wchodzące w związki składniowe z innymi leksemami. Drugą z wyróżnionych klas Wróbel dzieli na leksemy funkcjonujące jako człony zdania i leksemy niemające tej cechy (muszą one współwystępować z innymi leksemami lub strukturami złożonymi). Do obu klas autor odnosi w sposób niezależny kryterium 
funkcji łączącej. W wyniku jego zastosowania za leksemy funkcjonujące jako człony zdania i mające funkcję łączącą uznaje względniki (akomodowane) i relatory (nieakomodowane), a za leksemy niefunkcjonujące jako człony zdania i mające funkcję łączącą - przyimki (mające rząd przypadkowy) i spójniki (niemające rządu).

W klasyfikacji funkcjonalnej Zofii Zaron (2003), opartej na właściwościach konotacyjnych i akomodacyjnych leksemów, nie są wyróżniane zaimki względne ani też żadna inna klasa, do której mogłyby one należeć. Zaproponowana przeze mnie również na początku tego stulecia (Grochowski 2003) klasyfikacja polskich leksemów synsyntagmatycznych, w której dominowało kryterium szyku, nie obejmowała relatorów, uznanych za autosyntagmatyki.

\section{Podsumowanie: relatory i spójniki współcześnie}

Z teorii opisu semantycznego spójników polskich Jadwigi Wajszczuk (1997) wyrosła jej autorska koncepcja podziału składniowego leksemów, motywowanego semantycznie. Autorka zaproponowała nowe kryteria podziału jednostek wynikające z rozróżnienia poziomu przedmiotowego języka i poziomu meta, falsyfikując równocześnie kilka rozpowszechnionych, ale nieoperatywnych kryteriów, takich jak np. samodzielność składniowa leksemów czy ich zdolność do łączenia zdań bądź składników zdań. Na najwyższych piętrach podziału Wajszczuk (2010: 25) wprowadziła rozróżnienie leksemów (jednostek otwierających jakieś pozycje) i paraleksemów (jednostek nieotwierających żadnych pozycji), a następnie te pierwsze podzieliła na syntaktemy (jednostki otwierające pozycje semantycznie nacechowane lub wchodzące na jedną z takich pozycji) i parataktemy (jednostki niemające żadnej z tych cech). Nadrzędny podział syntaktemów polega na wyodrębnieniu trzech wielkich klas funkcjonalnych: a) syntaktemów, które nie otwierają żadnych pozycji, ale same zajmują pozycje otwierane przez inne wyrażenia (terminały), b) syntaktemów, które otwierają pozycje dla innych wyrażeń, ale same nie zajmują pozycji otwieranych przez inne wyrażenia (predykaty niezależne), c) syntaktemów, które zarówno zajmują pozycje otwierane przez inne wyrażenia, jak i otwierają pozycje dla innych wyrażeń (predykaty zależne). Każda z tych trzech klas składa się z kilku podklas. Nie zostały wśród nich wymienione relatory (zaimki względne). Skoro jednak znane są niektóre ich cechy w świetle dotychczasowych klasyfikacji strukturalnych (Wróbel 1996; Laskowski 1998), to można sądzić, że ich właściwe miejsce jest w klasie predykatów zależnych.

Parataktemy otwierają pozycje nienacechowane gramatycznie (nie nakładają na nie ograniczeń strukturalnych) ani semantycznie (nie uzupełniają znaczeń wyrażeń występujących w tych pozycjach swoim własnym znaczeniem). Operują na składniku struktury tematyczno-rematycznej lub na całej strukturze. W przeciwieństwie do syntaktemów, jednostek poziomu przedmiotowego języka, parataktemy są ope- 
ratorami metatekstowymi, mówiący za ich pomocą komentuje treść wyrażeń wypełniających otwierane pozycje. Zbiór parataktemów tworzą spójniki i partykuły; pierwsze otwierają dwie pozycje, drugie jedną (por. Wajszczuk 2010: 29-30; Grochowski, Kisiel, Żabowska 2014: 25-26).

Prace Wajszczuk pozwalają na stwierdzenie, że opozycja relatorów i spójników jest pochodną nadrzędnego dla nich przeciwstawienia syntaktemów i parataktemów oraz że relatory należą do przedmiotowego poziomu języka, a spójniki reprezentują poziom metatekstu. Jednostki obu porównywanych klas jako wyrażenia funkcyjne stanowiły w ostatnich latach przedmiot zespołowych prac leksykograficznych w WSJP PAN. W artykule podsumowującym zasady wyróżniania jednostek funkcyjnych przypisaliśmy relatorom i spójnikom następujące właściwości.

Relator to syntaktem zajmujący pozycję składnika wypowiedzenia zależnego i otwierający dwustronnie pozycje nacechowane semantycznie - przyłącza wypowiedzenie zależne do składnika wypowiedzenia głównego lub do samego wypowiedzenia głównego.

Spójnik to parataktem otwierający dwustronnie pozycje dla innych wyrażeń, nienacechowany semantycznie ani strukturalnie.

W przeciwieństwie do relatorów spójniki nie zajmują pozycji składnika wypowiedzenia (Grochowski, Kisiel, Żabowska 2018: 192-193).

Ewolucja kryteriów wyróżniania części mowy, pokazana tu na przykładzie opisu zależności między relatorami a spójnikami w polskiej literaturze syntaktycznej od początku XX w. do początków XXI w., potwierdza tezę ogólną o istnieniu postępu w badaniu jednostek funkcyjnych. Nie ma takiej klasyfikacji leksemów na części mowy, która spełniałaby warunki poprawności logicznej, pozwoliłaby na umieszczenie wszystkich jednostek w wyznaczonych klasach i nie byłaby oparta na kryteriach ogólnikowych, graniczących z pustką informacyjną (takim kryterium jest np. zdolność jednych wyrażeń do łączenia innych). Nie ma idealnej klasyfikacji gramatycznej jednostek. Nie ma języka bez gramatyki, a tym samym bez części mowy. Kryteria podziału gramatycznego jednostek muszą być więc ulepszane bez końca.

\section{Literatura}

Bоввошsкi I., 1995, Tzw. konektory względne (relatory) a transformacja przenoszaca, [w:] M. Grochowski (red.), Wyrażenia funkcyjne w systemie i tekście. Materiały konferencji naukowej (Toruń 21-23 X 1993), Toruń, s. 69-77.

BogusŁawski A., 1976, O zasadach rejestracji jednostek języka, „Poradnik Językowy” nr 8, s. 356-364.

DoboszyńsKa-MarkiewiCz K., 2013, Operatory adnumeratywne w jezyku polskim. Dystrybucja i znaczenia, Warszawa.

GaERTNer H., 1938, Gramatyka wspótczesnego języka polskiego. Głosownia - semantyka stowotwórstwo, Lwów - Warszawa. 
Grochowsкi M., 1984, Projekt klasyfikacji syntaktycznej polskich leksemów nieodmiennych, „Polonica” X, s. 73-97.

Grochowsкi M., 1986, Polskie partykuły. Składnia, semantyka, leksykografia, Wrocław.

Grochowsкi M., 1997, Wyrażenia funkcyjne. Studium leksykograficzne, Kraków.

Grochowsкi M., 2003, Szyk jednostek synsyntagmatycznych w języku polskim (główne problemy metodologiczne), „Polonica” XXII-XXIII, s. 203-223.

Grochowsкi M., 2011, Zenona Klemensiewicza koncepcja składnika wypowiedzenia w świetle współczesnej składni semantycznej, [w:] R. Majkowska, E. Fiałek (red.), Zenon Klemensiewicz 1891-1969. Materialy z posiedzenia naukowego $w$ dniu 19 czerwca 2009 r., „W Służbie Nauki” nr 18, Kraków, s. 47-58.

Grochowski M., Kisıel A., Żabowska M., 2014, Słownik gniazdowy partykuł polskich, Kraków.

Grochowski M., Kisiel A., ŻABowska M., 2018, Zasady opisu jednostek funkcyjnych w WSJP PAN, [w:] P. Żmigrodzki, M. Bańko, B. Batko-Tokarz, J. Bobrowski, A. Czelakowska, M. Grochowski, R. Przybylska, J. Waniakowa, K. Węgrzynek (red.), Wielki słownik jezyka polskiego PAN. Geneza, koncepcja, zasady opracowania, praca zbiorowa, Kraków 2018, s. 191-203.

HeInz A., 1978, Dzieje językoznawstwa w zarysie, Warszawa.

JodŁowski S., 1971, Studia nad częściami mowy, Warszawa.

JodŁowski S., 1976, Podstawy polskiej składni, Warszawa.

Karolak S., 1984, Składnia wyrażeń predykatywnych, [w:] Z. Topolińska (red.), Gramatyka współczesnego języka polskiego. Składnia, Warszawa, s. 11-211.

KLemensiewicz Z., 1937, Składnia opisowa współczesnej polszczyzny kulturalnej, Kraków.

Klemensiewicz Z., 1938, Gramatyka współczesnej polszczyzny kulturalnej w zarysie, Lwów - Warszawa.

Klemensiewicz Z., 1960, Podstawowe wiadomości z gramatyki języka polskiego, wyd. 3, Warszawa.

Klemensiewicz Z., 1963, Zarys składni polskiej, wyd. 4, Warszawa.

Kleszczowa K., SzczePaneK A. (red.), 2014, Wyrażenia funkcyjne w perspektywie diachronicznej, synchronicznej i porównawczej, Katowice.

KrasnOwOLSKI A., 1909, Systematyczna składnia języka polskiego, wyd. 2 popr., Warszawa.

KuryŁowicz J., 1936/1979, Dérivation lexicale et dérivation syntaxique. Contribution à la théorie des parties du discours, „Bulletin de la Société de Linguistique de Paris” 37 (110), s. 79-92; pol. przekład: Derywacja leksykalna a derywacja syntaktyczna. Przyczynek do teorii części mowy (przeł. D. Kurkowska), [w:] H. Kurkowska, A. Weinsberg (red.), Językoznawstwo strukturalne. Wybór tekstów, Warszawa 1979, s. 148-157.

LASKOwski R., 1984, Funkcjonalna klasyfikacja leksemów: części mowy, [w:] R. Grzegorczykowa, R. Laskowski, H. Wróbel (red.), Gramatyka współczesnego języka polskiego. Morfologia, Warszawa, s. 26-37.

LASKOWsKi R., 1998, Funkcjonalna klasyfikacja leksemów: części mowy, [w:] R. Grzegorczykowa, R. Laskowski, H. Wróbel (red.), Gramatyka współczesnego języka polskiego. Morfologia, wyd. 2 zm., Warszawa, s. 52-65.

Maldjieva V., 1995, Non-inflected parts of speech in the Slavonic languages. Syntactic characteristics, Warszawa.

Milewski T., 1952/1971, Stanowisko składni w obrębie językoznawstwa, „Biuletyn Polskiego Towarzystwa Językoznawczego” XI, s. 74-92; przedruk w: A.M. Lewicki (red.), Problemy składni polskiej. Studia, dyskusje, polemiki z lat 1945-1970, Warszawa 1971, s. 17-36. 
Milewski T., 1965, Językoznawstwo, Warszawa.

SAlOni Z., 1974, Klasyfikacja gramatyczna leksemów polskich, „Język Polski” LIV, 1-2, S. 3-13, 93-101.

SKARŻYŃski M., 1994, Części mowy i ich kategorie w gramatykach polskich XIX i XX wieku (1817-1938), „Rozprawy Habilitacyjne UJ” nr 281, Kraków.

SKARŻYŃsKi M., 2001, W kręgu gramatyk polskich XIX i XX wieku, Kraków.

SWJP: B. Dunaj (red.), Słownik współczesnego języka polskiego, Warszawa 1996.

Szober S., 1957, Gramatyka języka polskiego, wyd. 4, Warszawa.

Ulitzka E., 2008, Podziały leksemów na części mowy w teorii gramatyki (przegląd propozycji klasyfikacyjnych ostatniego stulecia), „Polonica” XXIX, s. 45-79.

Ulitzka E., 2010, Relatory we współczesnych słownikach języka polskiego, „Prace Filologiczne" LVIII, s. 417-436.

Urbańczy S., 1993, Dwieście lat polskiego językoznawstwa (1751-1950), Kraków.

WAJszczuk J., 1997, System znaczeń w obszarze spójników polskich. Wprowadzenie do opisu, Warszawa.

WAJszczuK J., 2005, O metatekście, Warszawa.

Wajszczuk J., 2010, Functional Class (so Called „Part of Speech”) Assignment as a Kind of Meaning-Bound Word Syntactic Information, „Cognitive Studies” / "Études Cognitives” 10, s. $15-33$.

Wielki słownik języka polskiego PAN. Geneza, koncepcja, zasady opracowania, praca zbiorowa, red. P. Żmigrodzki, M. Bańko, B. Batko-Tokarz, J. Bobrowski, A. Czelakowska, M. Grochowski, R. Przybylska, J. Waniakowa, K. Węgrzynek, Kraków 2018.

Wierzbicka A., 1971, Metatekst w tekście, [w:] M.R. Mayenowa (red.), O spójności tekstu, Wrocław, s. 105-121.

Wiśniewski M., 1995, O funkcjach gramatycznych wyrażeń typu „oczywiście”, „pewnie”, „wykluczone”, [w:] M. Grochowski (red.), Wyrażenia funkcyjne w systemie i tekście. Materiały konferencji naukowej (Toruń 21-23 X 1993), Toruń, s. 159-170.

Wróbel H., 1996, Nowa propozycja klasyfikacji syntaktycznej polskich leksemów, [w:] idem (red.), Studia z leksykologii i gramatyki języków słowiańskich, Kraków, s. 53-6o.

WRóвеL H., 2001, Gramatyka języka polskiego, Kraków.

WSJP PAN: P. Żmigrodzki (red.), Wielki słownik języka polskiego PAN, [on-line:] wsjp.pl.

ZARON Z., 2003, Funkcjonalna klasyfikacja leksemów polskich (kolejna propozycja), [w:] M. Gębka-Wolak, I. Kaproń-Charzyńska, M. Urban (red.), Studia z gramatyki i leksykologii języka polskiego, Toruń, s. 179-188.

\section{The Evolution of Criteria for a Grammatical Classification of Lexemes (Relative Pronouns vs Conjunctions) Summary}

The paper discusses the evolution of the part-of-speech classification of Polish lexemes, and presents the changes in the criteria used to distinguish relative pronouns and conjunctions. The characterization has been based on important works in the field of theoretical Polish grammar, including textbooks, from the beginning of the $2 \mathrm{O}^{\text {th }}$ to the beginning of the $21^{\text {st }}$ century. The author distinguishes two breakthroughs in the history of grammar, the first caused by the influence on research into grammar of the connotation theory, and the other by the influence of the metatext theory. 